\title{
A comparative analysis of antibody repertoire against Staphylococcus aureus antigens in Patients with Deep-Seated versus Superficial staphylococcal Infections
}

\author{
Ashok Kumar ${ }^{12}$, Pallab Ray 2, Mamta Kanwar ${ }^{12}$, Meera Sharma ${ }^{2}$, Subhash Varma ${ }^{3}$ \\ 1. Kresge Eye Institute, School of Medicine, Wayne State University, Detroit, MI 48201 USA \\ 2. Departments of Medical Microbiology, Post Graduate Institute of Medical Education and Research, Chandigarh, India 160012 \\ 3. Internal Medicine, Post Graduate Institute of Medical Education and Research, Chandigarh, India 160012
}

Corresponding address: Dr. Ashok Kumar, Kresge Eye Institute, Wayne State University/School of Medicine, 4717 St. Antoine, Detroit, MI 48201 USA. Tel: (313) 577-7922 Fax: (313) 577-7781 E-mail: akuma@med.wayne.edu

Received: 2005.07.01; Accepted: 2005.08.23; Published: 2005.10.01

Immunoblot and an enzyme-linked immunosorbent assays were used to evaluate and compare IgG antibodies against S. aureus whole cell lysate, cell wall peptidoglycan and lipoteichoic acid to discriminate between deep-seated and superficial S. aureus infection. Serum samples were examined from patients with deep-seated $(\mathrm{n}=25)$ and superficial $(\mathrm{n}$ $=25) \mathrm{S}$. aureus infections and 15 healthy controls. Patients with deep-seated infections exhibited a large number of immuno-reactive bands in their IgG immunoblot profile as compared to those with superficial infections and healthy controls. Anti-staphylococcal IgG antibodies that reacted with two antigens of apparent molecular weight 110 and 98 $\mathrm{kDa}$ were specifically present in $96 \%$ (24/25) of patients with deep-seated infections, and were absent in, superficial and control sera. Moreover other Gram-positive and Gram-negative bacteria did not share these two unique antigens. The ELISA assays revealed significantly elevated levels of IgG antibodies to peptidoglycan (PG) in 18 of 25 (72\%) patients with deep infection and 15 of $25(60 \%)$ patients with superficial staphylococcal infection. The elevated levels of IgG antibodies to teichoic acid (TA) antigen were detected in all (100\%) deep-seated group patients and among $40 \%(10 / 25)$ patients with superficial infection. An increase in levels of antibodies to PG showed a positive correlation trend with levels of IgG antibodies to TA only in deep infection group. Thus immunoblot detection of these two unique antigens as well as detection of elevated antibodies against PG and TA may be useful for the discrimination of staphylococcal deepseated and superficial infection in humans.

K eywords: S. aureus, A ntibody response, Deep-seated infection, Immunoblot, ELISA

\section{Introduction}

Staphylococcus aureus, being a highly versatile organism, has the capacity to establish infections in a wide range of body sites. The infections caused by this species are often acute and pyogenic and, if untreated may spread to surrounding deeper tissues or to metastatic sites involving other organs, resulting in disseminated or deepseated infections which are life threatening [1]. It is one of the most successful human pathogens with ability to colonize and infect both hospitalized patients with or without compromised host defenses and healthy immunologically competent people in the community[2]. Further, the recent reports of reduced susceptibility to vancomycin [3] highlight the importance of understanding molecular epidemiology of $S$. aureus infections.

S. aureus has a diverse arsenal of components and products that contribute to the pathogenesis of infections. A great deal is known about the contribution of these bacterial factors to the development of infection, [1] considerably less is known about the host factors. Moreover approximately $30 \%$ of healthy individuals are colonized by S. aureus, usually in their anterior nares which serves as the major reservoir form where the organism can spread to the other parts of the body [4]. The proposed pathogenesis for endogenous infection would be that from the nose, the skin become colonized causing subsequent infection in patients with impaired skin site [5, 6]. Recent studies have shown that mucin appears to be a critical host surface, which is colonized, involves the interactions between staphylococcal proteins and mucin carbohydrate [4, 7]. The role of other factors such as secretory $\operatorname{IgA}$ is not clear. Immunity to $\mathrm{S}$. aureus infections and its role in pathogenesis remain poorly understood [8]. Although, there appears to be a little resistance to mucosal colonization by S. aureus, healthy individuals have a high degree of innate resistance to invasive staphylococcal infections [9]. Natural immunity in the host is attributed to epidermal and mucosal surface barriers and to intact cellular and humoral immune defense. Due to repeated natural exposure to $S$. aureus (as a constituent of normal flora) antibodies to $\mathrm{S}$. aureus exoproteins and cell wall components peptidoglycan (PG) [10], teichoic acid (TA) [11] and capsule are prevalent in humans [9]. But titers of these anti-staphylococcal antibodies are elevated after severe infections and this view is supported by a number of studies, which have shown that significantly elevated levels of antibodies to TA or PG can be detected in the vast majority of patients with $\mathrm{S}$. aureus invasive infections $[12,13]$. Many of these studies have demonstrated the rise in titer of antibodies against TA and PG during infections, but they in general, failed to reveal a correlation between antibody titer and immunity to these infections [10]. One exception is that antibodies to the staphylococcal exoprotein TSST-1 are associated with immunity to staphylococcal toxic shock syndrome in humans [14]. The data regarding the presence of antibodies during superficial S. aureus infections are not evaluated systematically.

In this study we therefore aimed at analyzing antibody responses against $\mathrm{S}$. aureus whole cell lysate and its cell wall antigens in patients with deep-seated and 
superficial staphylococcal infection. The comparison of antibody levels and responses might thus identify the patients with more risk of life threatening deep-seated infection as compare to self-limiting superficial infections. Furthermore the presence of an antibody response against these antigens may also add diagnostic information when patients with putative invasive $\mathrm{S}$. aureus infection are being evaluated.

\section{Material and Methods}

\subsection{Study population}

This study was approved by Institutional Ethics Committee and Dean's Doctoral Committee. A total of 50 patients were enrolled in the study. Group I include 25 consecutive cases admitted in Nehru Hospital, PGIMER, Chandigarh, India with clinical evidence of sepsis and bacteriological evidence of deep-seated $\mathrm{S}$. aureus infections as evidenced by isolation of organism from blood or an aspirate from deep-seated normally sterile site. Cases of prior trauma or penetrating injury were excluded. Group II consisted of another 25 consecutive cases with evidence of bacteriological proven $\mathrm{S}$. aureus infection limited to skin and/or subcutaneous soft tissue without any clinical or bacteriological evidence of invasion into deeper tissues. Fifteen healthy persons without any history of sepsis in the preceding three months were taken as controls. Single serum samples were obtained from all the subjects including the patients and healthy controls and preserved at $-20^{\circ} \mathrm{C}$ till further use.

\subsection{Bacterial strains}

A total of 50 clinical isolate of $S$. aureus from the two groups of patients were obtained from clinical bacteriology laboratory, department of Medical Microbiology, PGIMER, Chandigarh, India. A standard strain of S. aureus (ATCC-12600) was obtained from Microbial Type Culture Collection (MTCC) center of Institute of Microbial Technology, Sector 39, Chandigarh. This strain was used as reference strain.

The clinical isolates were identified on the basis of colony characteristics, gram stain morphology, coagulase production and mannitol fermentation [15]. All the strains were preserved in semisolid agar butts at $4^{\circ} \mathrm{C}$ and in BHI broth (Hi Media) with $15 \%$ glycerol at $-70^{\circ} \mathrm{C}$ till further use.

\subsection{Preparation of whole cell lysate}

All clinical isolates and the reference strain were plated on BHI agar plates and incubated at $37^{\circ} \mathrm{C}$ for $24 \mathrm{~h}$. A sweep of 4-6 colonies from these plates were inoculated into flasks containing $10 \mathrm{ml}$ of BHI broth and incubated at $37^{\circ} \mathrm{C}$ overnight in an orbital shaker. Subsequently, $1 \mathrm{~mL}$ of this growth culture was added to $50 \mathrm{~mL}$ of fresh medium and incubated at $37^{\circ} \mathrm{C}$ with constant shaking (150 rpm) for 8 to 10 hours, and bacterial growth was monitored by taking aliquots and measuring OD600 at various time intervals. The culture was stopped at mid-logarithmic phase $(\mathrm{OD} 600 \leq 0.5)$. The resulting broth cultures were centrifuged at $10,000 \mathrm{~g}$ for $15 \mathrm{~m}$ at $4^{\circ} \mathrm{C}$. The supernatant was discarded and the pellets were washed twice in sterile PBS ( $\mathrm{pH}$ 7.2). The pellets were finally resuspended in equal volume of sterile PBS and disrupted by shaking with glass beads (Braun; cell disruptor) for 2-3 min under constant cooling by liquid $\mathrm{CO}_{2}$ till $90 \%$ of the cells were broken. The unbroken cells were deposited by centrifugation at $12,000 \mathrm{~g}$ for $30 \mathrm{~m}$ at $4^{\circ} \mathrm{C}$ and the supernatant was preserved at $-70^{\circ} \mathrm{C}$ till further use. The protein content of the samples was estimated by method of Bradford [16] and adjusted to give a final conc. of 2$3 \mathrm{mg} / \mathrm{ml}$.

\subsection{Sodium dodecyl sulphate polyacrylamide gel electrophoresis (SDS-PAGE)}

Whole-cell protein profile of all S. aureus isolates was analysed by SDS-PAGE following the discontinuous buffer system of Laemmli [17]. Samples were prepared for PAGE by mixing in proportions of one part sample to 3 parts of sample buffer and boiling for $5 \mathrm{~min}$. Solubilised samples $(20 \mu \mathrm{l})$ were applied to wells in a $4 \%$ acrylamide stacking gel over a $10 \%$ acrylamide separating gel. Electrophoresis was performed using a Bio-Rad MiniProtean-II ${ }^{\circledR}$ apparatus with vertical slab gel $7 \mathrm{~cm}(\mathrm{~L}) \times 8 \mathrm{~cm}$ (W) $\times 0.75 \mathrm{~mm}(\mathrm{~T})$. The gels were run at constant voltage of $175 \mathrm{~V}$ until the bromophenol blue dye had reached the bottom over a period of $45 \mathrm{~min}-1 \mathrm{hr}$. Broad range molecular weight markers (Bio-Rad) were also run for molecular weight estimation of bands of interest. After the completion of electrophoresis the gels were removed and stained with Coomassie Brilliant Blue R-250. The gels were photographed and protein profiles of the isolates were compared.

\subsection{Immunoblotting}

The whole cell lysate of the clinical isolates and reference strain were run in SDS-PAGE as mentioned earlier using a Bio-Rad Mini-PROTEAN II® apparatus following manufacturer's instructions. Gels were equilibriated in transfer buffer and the separated proteins were transferred onto nitrocellulose (NC) paper (pore diameter, $45 \mu \mathrm{m})$ as described by electrophoretic transfer method of Towbin et al. [18], using a Bio-Rad Mini TransBlot ${ }^{\circledR}$ cell at $100 \mathrm{~mA}$ for $90 \mathrm{~m}$ at $4^{\circ} \mathrm{C}$ in transfer buffer.

After transfer the NC paper was cut vertically into strips, which were washed twice in PBS and soaked in blocking buffer overnight at $4^{\circ} \mathrm{C}$. For characterization of serological response of patients to blotted and blocked NCP strips, patient sera diluted 1:100 in PBST containing $1 \%$ BSA were added to individual strips. After incubation at $37^{\circ} \mathrm{C}$ for $1 \mathrm{hr}$ at $37^{\circ} \mathrm{C}$, the strips were washed on a rotatory shaker with five changes of PBST for $10 \mathrm{~m}$ each. Anti-human IgG-HRPO conjugate (Dako) diluted 1:1000 in PBST-BSA were added to each strip and incubated for another one hour at $37^{\circ} \mathrm{C}$. Following five washings for 10 $\mathrm{m}$ each the strips were developed by soaking for $5 \mathrm{~m}$ in developing solution containing $0.05 \%(\mathrm{w} / \mathrm{v})$ diaminobenzidine tetrahydrochloride and $1 \% \mathrm{H}_{2} \mathrm{O}_{2}$ in PBS. The blots were dried and photographed.

\subsection{Preparation of $S$. aureus cell wall antigens}

S. aureus grown on nutrient agar plates overnight were resuspended in distilled water and heated at $70^{\circ} \mathrm{C}$ for $1 \mathrm{hr}$. The bacteria were centrifuged, rinsed twice with distilled water, twice with acetone and dried. Cells were disrupted in cell homogenizer (Braun, Germany) with glass beads $(0.17-0.18 \mathrm{~mm}$ dia). Residues upon centrifugation at 3,000 $\mathrm{rpm}$ for $10 \mathrm{~min}$ were discarded and from the supernatant cell wall were sedimented by centrifugation at 13,000 rpm for $25 \mathrm{~min}$ and rinsed 3 times with distilled water. Cell wall pellet was resuspended in phosphate buffer ( $\mathrm{pH} 7.6)$ containing trypsin $(200 \mu \mathrm{g} / \mathrm{ml})$, RNase $(100 \mu \mathrm{g} / \mathrm{ml})$ and DNase $(50 \mu \mathrm{g} / \mathrm{ml})$ and incubated at 
$37^{\circ} \mathrm{C}$ for $18 \mathrm{~h}$, rinsed 3 times with distilled water and lyophilized.

\subsubsection{Teichoic Acid extraction}

Teichoic acid was extracted from cell wall fractions with 5\% TCA at room temp 3 times overnight on shaker (1g cell wall per $250 \mathrm{ml}, 160 \mathrm{ml}$, and $100 \mathrm{ml}$ of TCA). Three aliquots of supernatant were pooled and extracted 3 times with double volume of ethyl ether each time and then precipitated with 3 volumes of acetone at $4^{\circ} \mathrm{C}$ for $24 \mathrm{hrs}$. Delicate precipitates of teichoic acid were centrifuged and washed with acetone and dried.

\subsubsection{Peptidoglycan preparation}

The residue remaining from cell wall extraction with TCA was heated at $90^{\circ} \mathrm{C}$ for $15 \mathrm{~min}$, washed with water 3 times, followed by acetone and dried. This fraction was used as peptidoglycan in all experiments as described by Kotani et al $[19,20]$.

In addition commercially available Staphylococcus aureus peptidoglycan and teichoic acid purchased from Sigma were also included in ELISA experiments.

\subsection{ELISA}

The modification of the technique originally described by Engvall and Perlamann [21] was used to quantitate IgG antibodies against cell walls peptidoglycan (PG) and teichoic acid (TA) in patients and healthy control sera. One hundred microliters of antigen solution $(10 \mu \mathrm{g} / \mathrm{ml})$ in carbonate buffer $(\mathrm{pH}$ 9.6) was added to flat bottom microtiter plate (Maxisorp, Nunc, Denmark) wells and left to adsorb for $1 \mathrm{~h}$ at $37^{\circ} \mathrm{C}$ and then overnight at $4^{\circ} \mathrm{C}$. The plates were then washed (SLT washer, Austria) in PBST. The unbound sites on the plastic surface were blocked with $200 \mu \mathrm{l}$ of PBS containing $2 \%$ BSA. The blocking agent was left for $6 \mathrm{~h}$ at room temperature and then overnight at $4^{\circ} \mathrm{C}$. The plates were washed 3 times

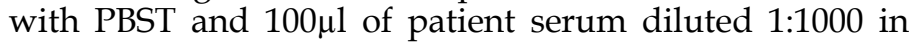
PBST containing 1\% BSA was added to each well and the plate was kept for incubation at $37^{\circ} \mathrm{C}$ for $1 \mathrm{~h}$. After washing (five times) $100 \mu \mathrm{l}$ of anti-human IgG-HRP conjugate diluted in PBST containing 1\% BSA was added and incubated at $37^{\circ} \mathrm{C}$ for $1 \mathrm{~h}$. After washing $100 \mu \mathrm{l}$ of substrate containing $10 \mathrm{mg}$ of orthophenylene diamine (OPD) in $25 \mathrm{ml}$ of citrate-phosphate buffer was added to each well. After 15-20 mins at room temperature, the reaction was stopped with $50 \mu \mathrm{l}$ of $2.5 \mathrm{M} \mathrm{H}_{2} \mathrm{SO}_{4}$. The plates were read in an automated ELISA reader (340 ATC, SLT, Austria) at $492 \mathrm{~nm}$ using a reference wavelength of 620 $\mathrm{nm}$. The results of the assay were expressed as the mean optical density at $492 \mathrm{~nm}$ of the duplicate values. Statistical analysis was performed using ANOVA and $\mathrm{p}<$ 0.05 were considered to be significant.

\section{Results}

\subsection{Demographics}

A total of 50 patients and 15 healthy controls were enrolled in the study. The patients with deep-seated infections had deep abscesses $(n=8)$, sepsis $(n=5)$, endocarditis $(n=4)$, pyomyositis $(n=3)$, septic arthritis and osteomyelitis $(n=2$ each) and empyema $(n=1)$. The mean age of patients in this group was 24.5 years (range, 4 to 65 years). Patients with superficial infections had pyoderma $(\mathrm{n}=11)$, folliculitis $(\mathrm{n}=8)$, subcutaneous abscesses $(n=5)$ and sty $(n=1)$ and the mean age in this group was 21.1 years (range, 4 to 52 years). The patients with deep-seated infections were admitted in different wards of Nehru Hospital, PGIMER, Chandigarh during a period of 2 years from Jan 1999 to March 2001, while the majority $(80 \%)$ of patients with superficial infections enrolled in the study were taken from skin OPD over a period of 3 months March 2001 to May 2001. The S. aureus strains from clinical specimens of hospitalized patients were recovered within two to three days after hospitalization, whereas strains were isolated next day from those appearing in OPDs (particularly skin). Serum samples were also collected same day before the start of antibiotic therapy.

\subsection{S. aureus strains causing deep-seated and superficial infection had identical protein profile}

Recently, S. aureus strains have been shown to have an association to the type of infection [22]. In order to compare the whole cell protein profile of $\mathrm{S}$. aureus strains associated with deep-seated and superficial infection, whole cell lysates of isolates of both the groups were subjected to SDS-PAGE. Both deep and superficial isolates showed almost identical protein profile which consisted of 25-30 bands with major bands having molecular weights of approximately 120, 92, 80, 66, 55, 42, 36, 29, 24, 20, 18 and $16 \mathrm{kDa}$ (Fig 1).

The protein profiles of isolates within the same group were grossly similar. More than $90 \%$ of the bands were qualitatively and quantitatively identical with minor quantitative difference in the intensity of the others. No significant inter strain variation was found among the deep and superficial isolates regarding their whole cell protein profile.

\subsection{Immunoblot profile can discriminate between deep- seated and superficial infection}

The IgG antibody response to whole cell lysate of Staphylococcus aureus during infection was examined qualitatively by immunoblot analysis of sera from patients of both the group. Figure 2 shows the IgG immunoblot profile of the sera of patients with deep-seated and superficial infections respectively. Sera from patients with deep-seated staphylococcal infections exhibited a large number of bands in their IgG western blot profile (Fig; 2A) as compared to those with superficial infections (Fig; 2B). The banding patterns within each group of patients were grossly similar with minor individual variations. The most prominent band present in both superficial and deep patient sera had molecular weight of approximately 60 $\mathrm{kDa}$. This band was also detected in healthy controls (data not shown). In addition to this common band, the immunoblot profile of deep-seated group of patients showed the presence of two unique bands with molecular weights of $110 \mathrm{kDa}$ and $98 \mathrm{kDa}$ which were detected in $96 \%$ of patients of this group but were totally absent in patients with superficial infection and healthy individuals.

\subsection{The 110 and $98 \mathrm{kDa}$ immunodominant peptide of $S$. aureus are not shared by other bacteria}

In order to demonstrate the species specificity of these two unique bands present in IgG immunoblot profile of patient sera from deep-seated infections, pooled sera from patients of both the groups and healthy controls were checked against whole cell proteins of other Grampositive [S. epidermidis and clinical isolates of coagulasenegative staphylococci (CONS)] and Gram-negative (E. coli, Klebsiella spp) bacteria. The results of this experiment showed that these two bands were present only in cases 
with deep seated infections (Fig. 3A) and absent from those with superficial infections (Fig. 3B) and healthy controls (Fig. 3C). Moreover these antigens were not shared by other Gram-positive and Gram-negative bacteria tested.

\subsection{Anti-staphylococcal antibodies react with $P G$ and $T A$}

We observed that levels of anti-staphylococcal IgG antibodies were very similar when total bacterial lysate or whole S. aureus cells were used as coating antigens (data not shown). These results suggested that the majority of antistaphylococcal IgGs reacted with the surface of the pathogen. TA and PG, the two most abundant cell wall components, have been known to be highly immunogenic in humans. Consistent with this notion, the quantitative measurement of IgG antibodies to peptidoglycan and teichoic acid in sera from patients and healthy controls was checked by ELISA.

The sera obtained from both patients and healthy controls showed great variability in levels of antibodies against S. aureus cell wall antigens (table 1). Sera from patients were considered positive if the OD exceeded the mean OD of healthy control sera plus one SD. Elevated levels of IgG antibodies to teichoic acid antigen were detected in $100 \%(25 / 25)$ patients with deep-seated infections and $40 \%(10 / 25)$ of patients with superficial infection. About $72 \%(18 / 25)$ of patients among deep group and $60 \%(14 / 25)$ among superficial had significantly elevated antibodies against peptidoglycan (Fig. 4). The levels of antibodies against cell wall antigens also varied within each group, amongst deep infection group 4 of 25 patients who had staphylococcal endocarditis and two patients with osteomyelitis were found to have higher antibodies to TA and PG, as compare to other patients in this group. Similarly patients with folliculitis had higher levels of antibodies to PG among superficial group. Similar results were obtained when we used the commercially available PG and TA

\subsection{Correlation coefficients}

We analyzed the correlation of levels of antipeptidoglycan and teichoic acid antibodies in sera from patients with deep-seated and superficial staphylococcal infections. Sera from patients with deep-seated infections showed weak positive correlation trend between antibodies to PG and TA ( $p<0.1)$, where as on the other hand no significant correlation was detected among patients with superficial infections regarding anti PG and TA antibody levels (Fig. 5).

\section{Discussion}

Staphylococcus aureus is a major human pathogen causing significant morbidity and mortality in both community and hospital acquired infections [1]. It causes a diverse array of infections ranging from relatively minor skin and wound infections to more serious and life threatening disease such as pneumonia, endocarditis, osteomyelitis, arthritis and sepsis [2]. Here in this study we investigated the prevalence of antibodies to the wellcharacterized staphylococcal cell wall antigens PG and TA and total cell lysate in sera from patients with deep-seated and superficial S. aureus infections. We demonstared that the patients with deep-seated infection can be discriminated from those with superficial infection, which might thus identify the patients with more risk of life threatening deep-seated infection as compare to selflimiting superficial infections.
Immunoblotting of bacterial whole cell polypeptides, by the western blot technique has been used to examine the immune response of individuals to the large number of polypeptides found in whole cell extract pathogenic bacteria [23] including Staphylococcus aureus [24]. In a study of six patients with $\mathrm{S}$. aureus endocarditis, antibodies to $\mathrm{S}$. aureus and E.coli heat shock proteins were detected by western immunoblots, but a similar response was observed in sera from patients with other forms of endocarditis. While heat shock proteins may not be as specific as staphylococcal antigens studied by ColgueNavarro and collegues as these results emphasise that serological response to staphylococcal infection is complex partly because individuals are exposed to $S$. aureus from birth [25]. Our study has clearly demonstrated that all the individuals (patients and controls) investigated produce circulating antibodies directed against a large number of $\mathrm{S}$. aureus polypeptides. This finding is in agreement with those of other workers who have documented those most human sera posses a variety of anti-staphylococcal antibodies [26]. Despite the complexity of immune response many polypeptides in the cell extract gave negative reaction in the western blot analysis. It is likely that the immune response against some polypeptides may be poor because they are intrinsically poor antigens, because of their structure or other factors [27]. Western blot of IgG response of patients with deep-seated infections showed antibodies against a large number of polypeptides as compared to those with superficial infections. In immunoblot profile of deepseated patients we identified two unique polypeptides of molecular weights of approximately $110 \mathrm{kDa}$ and $98 \mathrm{kDa}$, which were detected exclusively in $96 \%$ of patients with deep-seated infection, and they were absent in superficial group and healthy control group. These two unique bands are likely to be of diagnostic value. The diagnostic efficacy of antibody detection tests was not the primary objective of this study and these findings need to be further evaluated in larger group of patients and healthy individuals. In addition further characterization of these two polypeptide antigens is required to evaluate their potential role in diagnosis of these two groups of patients.

In recent years attention has been focused on the measurement of antibody to cell wall antigens in patients with proven S. aureus infection [28]. Teichoic acid and peptidoglycan are the major components of staphylococcal cell wall and they are known to induce inflammatory response in humans [29]. Antibodies against PG and TA antigens have been successfully titred in serological assays [28, 30, 31]. Humoral immune response to $\mathrm{S}$. aureus infections is complex and despite the fact that $\alpha$-toxin, teichoic acid and lipase are widely recognized as staphylococcal virulence determinants, the production of antibodies to one or more antigens is variable. Colque-Navarro and colleagues acknowledge that the kinetics of the antibody response differs greatly between patients [25]. In our study, we also observed variable antibody response against $\mathrm{S}$. aureus cell wall antigens peptidoglycan and teichoic acid between both the groups of patients and healthy controls. Studies are available which have shown the increased IgG titer against teichoic acid [32] in patients with deep-seated staphylococcal infections (especially in cases of endocarditis and ostemyelitis). We also observed that all $(25 / 25)$ of the patients with deep-seated infection had elevated levels of IgG antibodies against TA, even with in 
the group of patients with endocarditis and osteomyelitis showed higher levels than rest of the group. Two healthy controls also exhibited higher antibodies against this antigen. Previous staphylococcal infections or non-specific antibody responses may be a significant factor in partly explaining the high initial antibody levels [33, 34]. In contrast, failure to mount an antibody response against PG in some of the patients with deep infection might be due to impaired immunity of advancing age, poor expression of virulence determinants by the infecting strain or changes in the immune response resulting from infection itself.

Verbrugh et al. [35], in 1986 undertook one study to compare the antibody response to $\alpha$-toxin, teichoic acid and peptidoglycan in patients with complicated and uncomplicated infections. Neither single test was able to detect complicated bacteraemia in all patients nor there do any test that was totally specific in this respect. Sensitivities ranged from $64 \%$ for assay of Abs against teichoic acid to $72 \%$ for assays of antibody to peptidoglycan and $\alpha$-toxin. The specificity of assays for antibody to cell wall antigens (peptidoglycan and teichoic acid) was $79 \%$ whereas this specificity was $50 \%$ for $\alpha-$ toxin. Our data indicated a positive correlation trend between raised levels of antibodies to PG and TA among deep infection group, but surprisingly no correlation was detected among superficial infection group.

In conclusion our data indicated that patients with deep-seated and superficial staphylococcal infection can be discriminated on the basis of their immunoblot profile against total S. aureus cell lysate as well as their serum IgG response to cell wall antigens peptidoglycan and teichoic acid. Whether the presence of antibodies against these cell wall antigens of $S$. aureus decreases or enhances the outcome of staphylococcal infection is still not clear.

\section{Acknowledgements}

We gratefully acknowledge Ph.D. research fellowship to A.K from the PGIMER. The authors also thank Chaesik Kim for statistical analysis, David Griffith for photography and Dr. Fu-Shin Yu (Kresge Eye Institute) for his valuable critiques.

\section{Conflict of interest}

None declared.

\section{References}

1. Lowy FD. Staphylococcus aureus infections. N Engl J Med 1998, 339(8):520-532.

2. Lyytikainen O, Ruotsalainen E, Jarvinen A, Valtonen V, Ruutu P. Trends and outcome of nosocomial and community-acquired bloodstream infections due to Staphylococcus aureus in Finland, 1995-2001. Eur J Clin Microbiol Infect Dis 2005; 24(6): 399-404.

3. Tenover FC, Biddle JW, Lancaster MV. Increasing resistance to vancomycin and other glycopeptides in Staphylococcus aureus. Emerg Infect Dis 2001, 7(2):327-332.

4. Peacock SJ, de Silva I, Lowy FD. What determines nasal carriage of Staphylococcus aureus? Trends Microbiol 2001, 9(12):605-610.

5. Toshkova K, Annemuller C, Akineden O, Lammler C. The significance of nasal carriage of Staphylococcus aureus as risk factor for human skin infections. FEMS Microbiol Lett 2001, 202(1):17-24.

6. von Eiff C, Becker K, Machka K, Stammer H, Peters G. Nasal carriage as a source of Staphylococcus aureus bacteremia. Study Group. N Engl J Med 2001, 344(1):11-16.

7. Shuter J, Hatcher VB, Lowy FD. Staphylococcus aureus binding to human nasal mucin. Infect Immun 1996, 64(1):310-318.
8. Biesbrock AR, Reddy MS, Levine MJ. Interaction of a salivary mucinsecretory immunoglobulin A complex with mucosal pathogens. Infect Immun 1991, 59(10):3492-3497.

9. Lee JC. The prospects for developing a vaccine against Staphylococcus aureus. Trends Microbiol 1996, 4(4):162-166.

10. Jacob E, Durham LC, Falk MC, Williams TJ, Wheat LJ. Antibody response to teichoic acid and peptidoglycan in Staphylococcus aureus osteomyelitis. J Clin Microbiol 1987, 25(1):122-127.

11. Granstrom M, Julander I, Mollby R. Serological diagnosis of deep Staphylococcus aureus infections by enzyme-linked immunosorbent assay (ELISA) for staphylococcal hemolysins and teichoic acid. Scand J Infect Dis Suppl 1983, 41:132-139.

12. Tuazon CU, Sheagren JN. Teichoic acid antibodies in the diagnosis of serious infections with Staphylococcus aureus. Ann Intern Med 1976, 84(5):543-546.

13. Tuazon CU, Sheagren JN, Choa MS, Marcus D, Curtin JA. Staphylococcus aureus bacteremia: relationship between formation of antibodies to teichoic acid and development of metastatic abscesses. J Infect Dis 1978, 137(1):57-62.

14. Kanclerski K, Soderquist B, Kjellgren M, Holmberg H, Mollby R. Serum antibody response to Staphylococcus aureus enterotoxins and TSST-1 in patients with septicaemia. J Med Microbiol 1996, 44(3):171177.

15. Kloos WE BT. Staphylococcus and Micrococcus. In: manual of clinical microbiology. Washington, DC: American Society of Microbiology Press. 1995: 282-298.

16. Bradford MM. A rapid and sensitive method for the quantitation of microgram quantities of protein utilizing the principle of protein-dye binding. Anal Biochem 1976, 72:248-254.

17. Laemmli UK. Cleavage of structural proteins during the assembly of the head of bacteriophage T4. Nature 1970, 227(5259):680-685.

18. Towbin H, Staehelin T, Gordon J. Electrophoretic transfer of proteins from polyacrylamide gels to nitrocellulose sheets: procedure and some applications. 1979. Biotechnology 1992, 24:145-149.

19. Kotani S, Narita T, Stewart-Tull DE, Shimono T, Watanabe Y. Immunoadjuvant activities of cell walls and their water-soluble fractions prepared from various gram-positive bacteria. Biken J 1975, 18(2):77-92.

20. Kotani S, Watanabe Y, Shimono T, Kinoshita F, Narita T. Immunoadjuvant activities of peptidoglycan subunits from the cell walls of Staphyloccus aureus and Lactobacillus plantarum. Biken J 1975, 18(2):93-103.

21. Engvall E, Perlmann P. Enzyme-linked immunosorbent assay, Elisa. 3. Quantitation of specific antibodies by enzyme-labeled antiimmunoglobulin in antigen-coated tubes. J Immunol 1972, 109(1):129-135.

22. Booth MC, Pence LM, Mahasreshti P, Callegan MC, Gilmore MS. Clonal associations among Staphylococcus aureus isolates from various sites of infection. Infect Immun 2001, 69(1):345-352.

23. Chia JS, Chang WC, Yang CS, Chen JY. Salivary and serum antibody response to Streptococcus mutans antigens in humans. Oral Microbiol Immunol 2000, 15(2):131-138.

24. Pagani L, Debiaggi M, Garbagnoli P, Romero E. Immunoblot typing of oxacillin-resistant Staphylococcus aureus clinical isolates. J Chemother 1991, 3 (Suppl 1):172-175.

25. Colque-Navarro P, Soderquist B, Holmberg H, Blomqvist L, Olcen P, Mollby R. Antibody response in Staphylococcus aureus septicaemia-a prospective study. J Med Microbiol 1998, 47(3):217-225.

26. Bell JA, Pennington TH, Petrie DT. Western blot analysis of staphylococcal antibodies present in human sera during health and disease. J Med Microbiol 1987, 23(2):95-99.

27. Orden JA, Goyache J, Hernandez J, Domenech A, Suarez G, GomezLucia E. Applicability of an immunoblot technique combined with a semiautomated electrophoresis system for detection of staphylococcal enterotoxins in food extracts. Appl Environ Microbiol 1992, 58(12):4083-4085.

28. Verbrugh HA, Van Dijk WC, Peters R, Van Der Tol ME, Verhoef J. The role of Staphylococcus aureus cell-wall peptidoglycan, teichoic acid and protein $\mathrm{A}$ in the processes of complement activation and opsonization. Immunology 1979, 37(3):615-621.

29. Kumar A, Zhang J, Yu FS. Innate immune response of corneal epithelial cells to Staphylococcus aureus infection: role of 
peptidoglycan in stimulating proinflammatory cytokine secretion. Invest Ophthalmol Vis Sci 2004, 45(10):3513-3522.

30. Verbrugh HA, Peters R, Rozenberg-Arska M, Peterson PK, Verhoef J. Antibodies to cell wall peptidoglycan of Staphylococcus aureus in patients with serious staphylococcal infections. J Infect Dis 1981, 144(1):1-9.

31. Martin RR, Greenberg SB, Wallace RJ. Staphylococcal teichoic-acid antibodies. Lancet. 1979;1(8118):731.

32. Ayyagari A, Pal N. Antiribitol-teichoic acid antibody (ARTA) in diagnosis of deep seated Staphylococcus aureus infections. Indian J Pathol Microbiol 1991, 34(3):176-180.

33. Colque-Navarro P, Palma M, Soderquist B, Flock JI, Mollby R. Antibody responses in patients with staphylococcal septicemia against two Staphylococcus aureus fibrinogen binding proteins: clumping factor and an extracellular fibrinogen binding protein. Clin Diagn Lab Immunol 2000, 7(1):14-20.

34. Verbrugh HA, Verhoef J, Wilkinson BJ, Peterson PK. Biology and clinical significance of peptidoglycan antibody response in staphylococcal infections. Scand J Infect Dis Suppl 1983, 41:117-125.

35. Verbrugh HA, Peters R, Goessens WH, Michel MF. Distinguishing complicated from uncomplicated bacteremia caused by Staphylococcus aureus: the value of "new" and "old" serological tests. J Infect Dis 1986, 153(1):109-115.

\section{Tables and Figures}

Table 1. IgG antibody levels against PG and TA in sera from healthy individuals and patients with deep-seated and superficial staphylococcal infections.

\begin{tabular}{|c|c|c|c|c|c|c|c|c|c|}
\hline \multirow[t]{2}{*}{$\begin{array}{l}\text { S. aureus cell } \\
\text { wall } \\
\text { Antigens }\end{array}$} & \multicolumn{3}{|c|}{$\begin{array}{c}\text { Healthy } \\
\text { Individuals }(\mathrm{n}= \\
15)\end{array}$} & \multicolumn{3}{|c|}{$\begin{array}{c}\text { Patients with } \\
\text { Superficial } \\
\text { Infection }(n=25)\end{array}$} & \multicolumn{3}{|c|}{$\begin{array}{c}\text { Patients with } \\
\text { Deep-seated } \\
\text { Infection }(n=25)\end{array}$} \\
\hline & Mean* & $\mathrm{SD}^{*}$ & $\mathrm{CV}$ & Mean* & $\mathrm{SD}^{*}$ & $\mathrm{CV}$ & Mean* & $\mathrm{SD}^{*}$ & $\mathrm{CV}$ \\
\hline Peptidoglycan & 0.78 & 0.29 & 0.37 & $1.05^{\mathrm{a}}$ & 0.57 & 0.54 & $1.39^{\mathrm{a}}$ & 0.70 & 0.50 \\
\hline Teichoic acid & 0.49 & 0.20 & 0.41 & 0.52 & 0.34 & 0.65 & $1.29 \mathrm{a}$ & 0.63 & 0.48 \\
\hline
\end{tabular}

$\mathrm{SD}$, Standard deviation; $\mathrm{CV}$, coefficient of variation

* Mean and SD are given as ODs at $492 \mathrm{~nm}$.

${ }^{\mathrm{a}} p<.05$
Figure 1. Whole-cell protein profile of representative $S$. aureus strains. Clinical isolates of $S$. aureus were taken from patients with deep-seated (A) and superficial staphylococcal infection (B). The crude protein extracts were separated by SDS-PAGE and stained with Coomassie blue. Lane M; molecular weight marker; Lane A; standard $S$. aureus strain (ATCC 12600); Lane 1-6; whole cell lysates of representative $S$. aureus isolates. Figures are representative of two independent experiments.

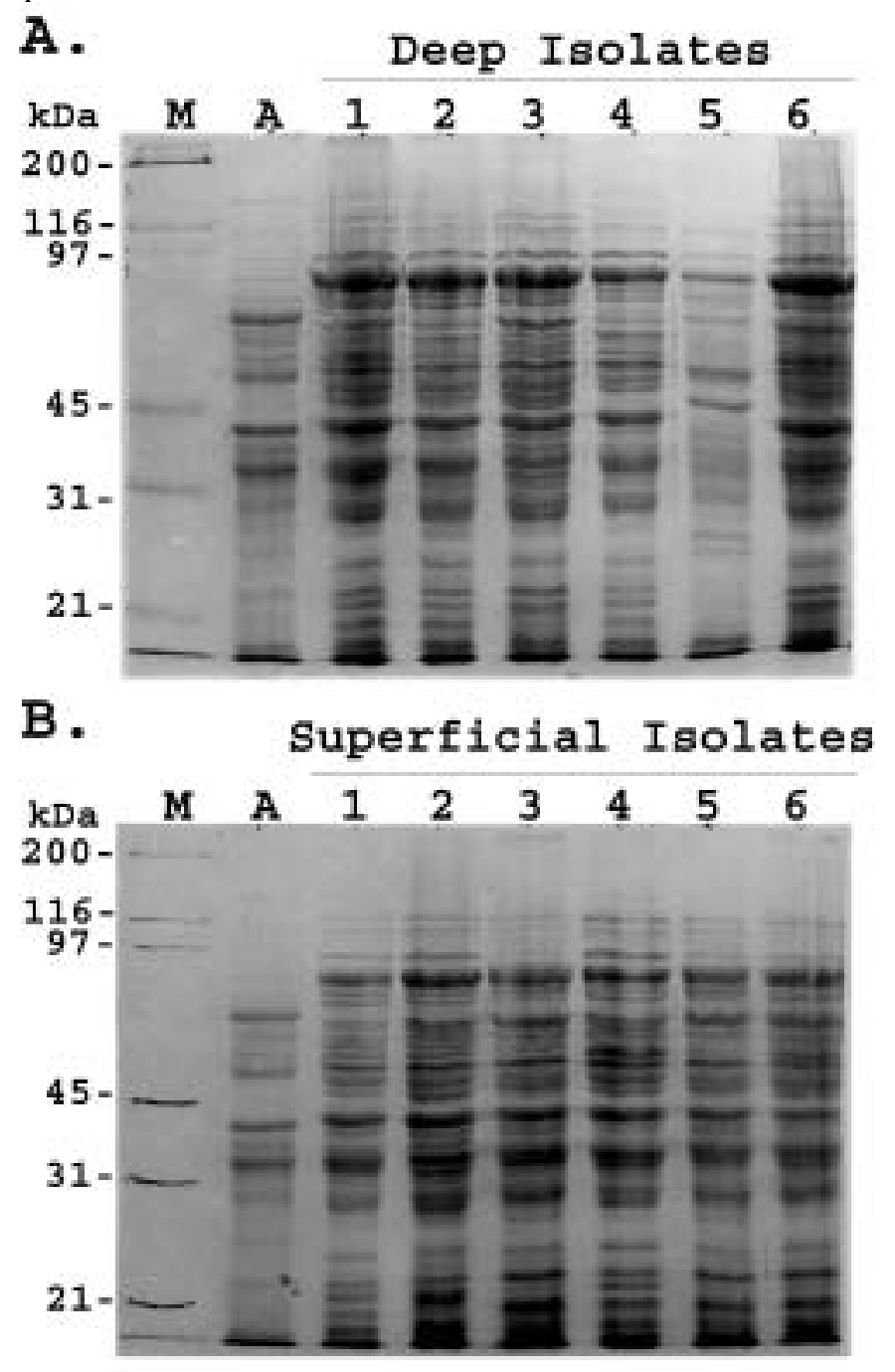


Figure 2. Immunoblot profiles of patients with deep-seated and superficial $S$. aureus infection. Whole cell protein lysate of $S$. aureus (ATCC 12600) was separated by SDS-PAGE and transferred onto nitrocellulose membranes which were probed with serum (1:1000) from patients with deep-seated $(\mathrm{A})$ and superficial (B) infection. Each lane represents serum from individual patients. Serum samples were drawn 2-3 day after detection of $S$. aureus in clinical specimens. Results are representative of two independent experiments.

A.
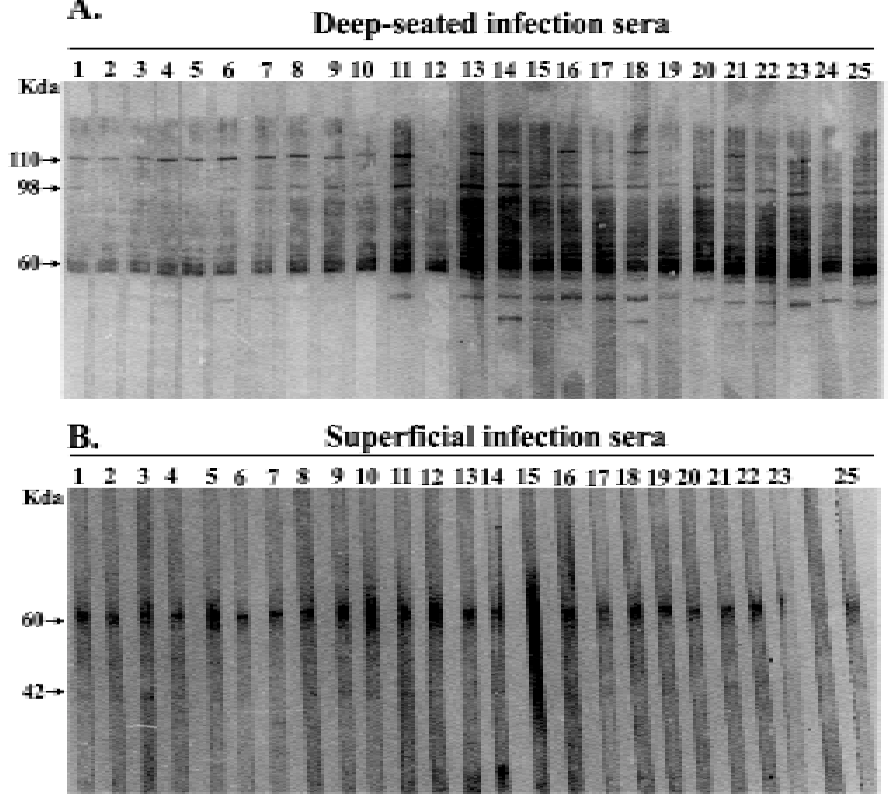

Figure 3. Western blot analysis of $S$. aureus immunodominant antigens. Whole cell protein lysate of $S$. epidermidis (lane 1), S. aureus (lane 2), clinical isolates of coagulase negative staphylococci (lane 3-5), E. coli (lane 5) and Klebsiella sp (lane 6) were separated by SDS-PAGE and transferred onto nitrocellulose membranes and probed with pooled serum $(1: 1000)$ from patients with deep-seated $(\mathrm{A})$ and superficial (B) infection and healthy controls (C). Results are representative of three independent experiments.
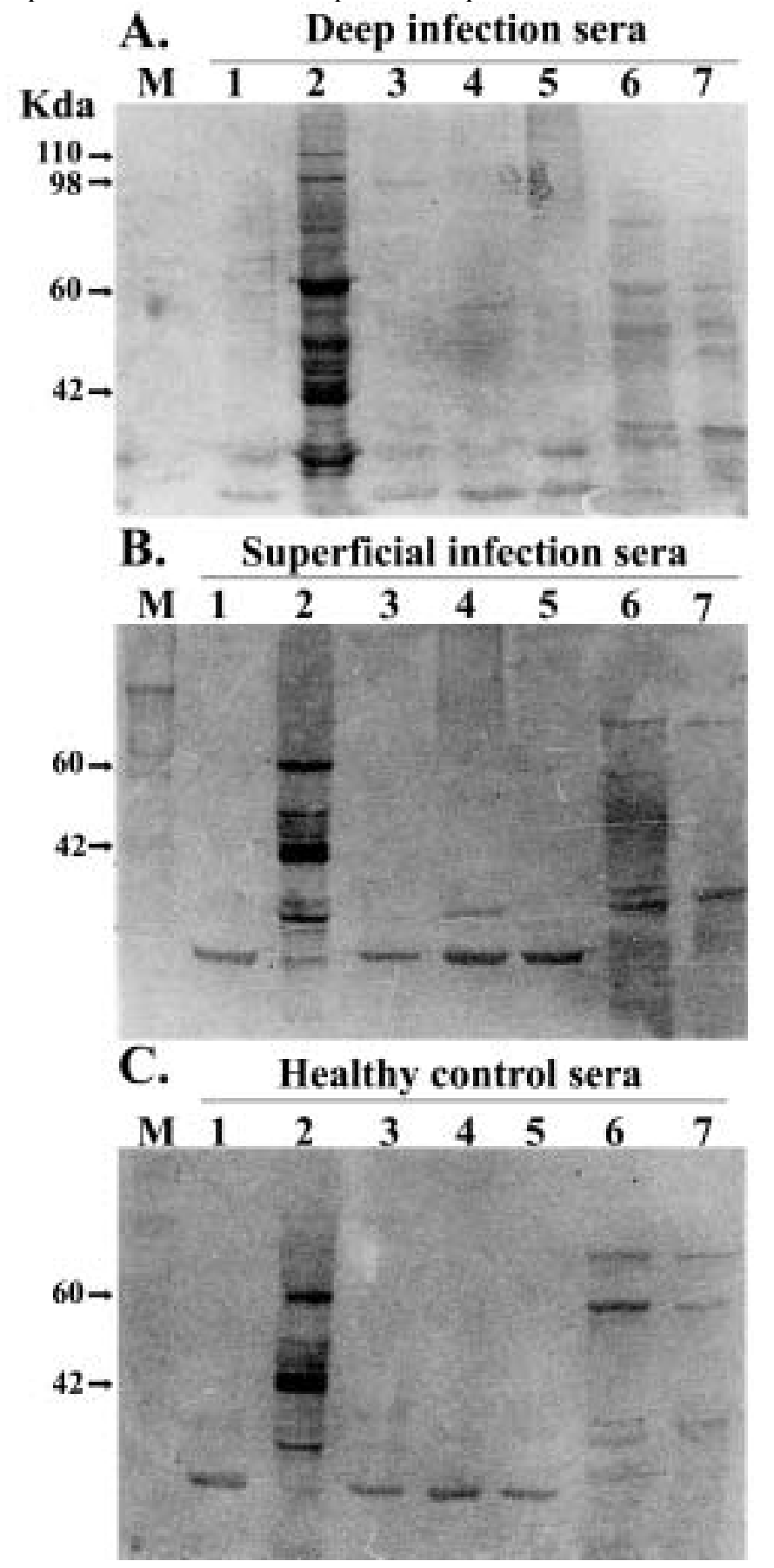
Figure 4. Levels of antistaphylococcal IgG antibodies. Antibodies against $S$. aureus cell wall antigen peptidoglycan (A) and teichoic acid (B) were measured ELISA in sera (1:1000) from helathy individuals and patients with superficial and deepseated infection. Violin plots were constructed on the basis of OD $492 \mathrm{~nm}$ to show the distribution IgG antibody levels in each group. Data are the representative of three independent experiments.

A.

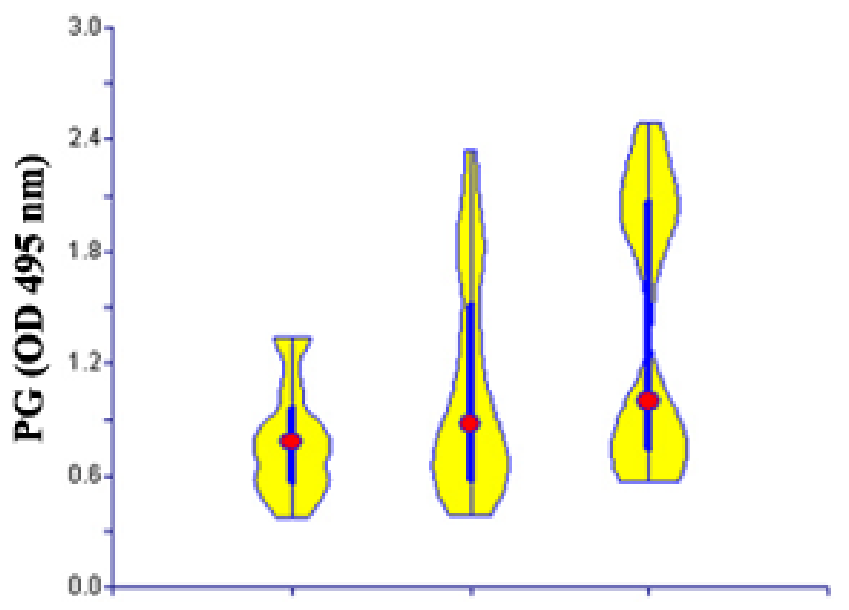

B.

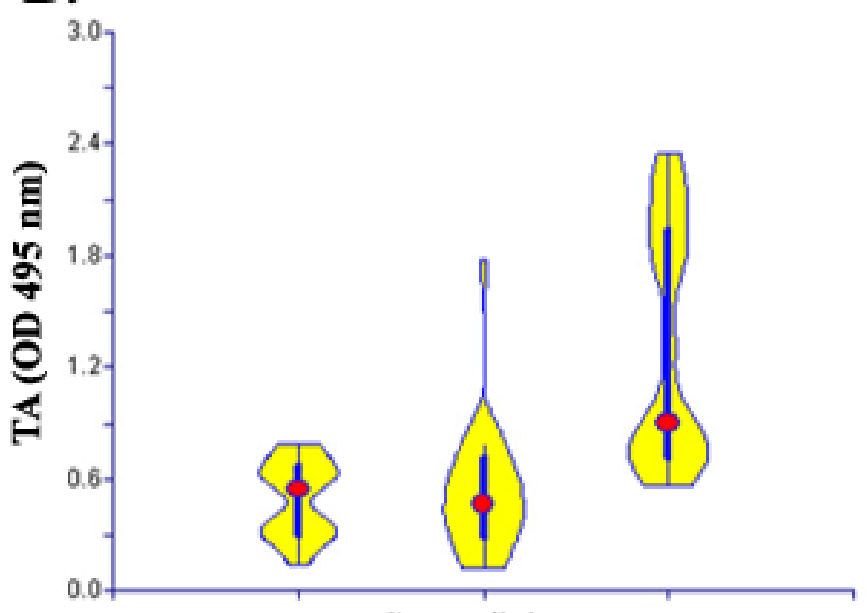

Figure 5. Correlation plots of antibodies to PG and TA. Antibody levels against peptidoglycan and teichoic acid in patients with superficial (A) and those with deep-seated (B) as measured by ELISA were plotted against each other to elucidate correlation. Coefficient of correlation was determined by $r^{2}$ values as shown. Results represent the values of experiment in duplicates.

A.

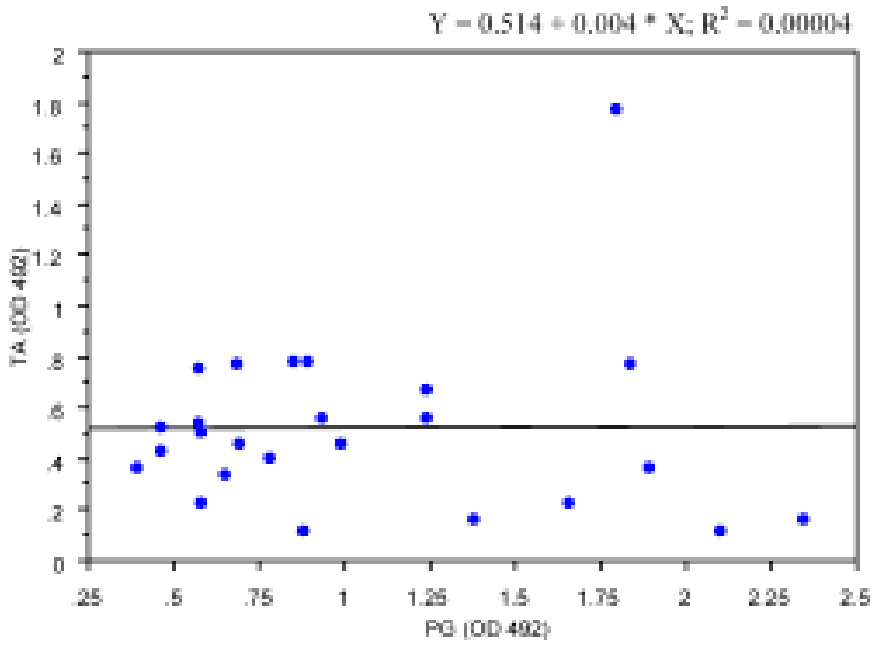

B.

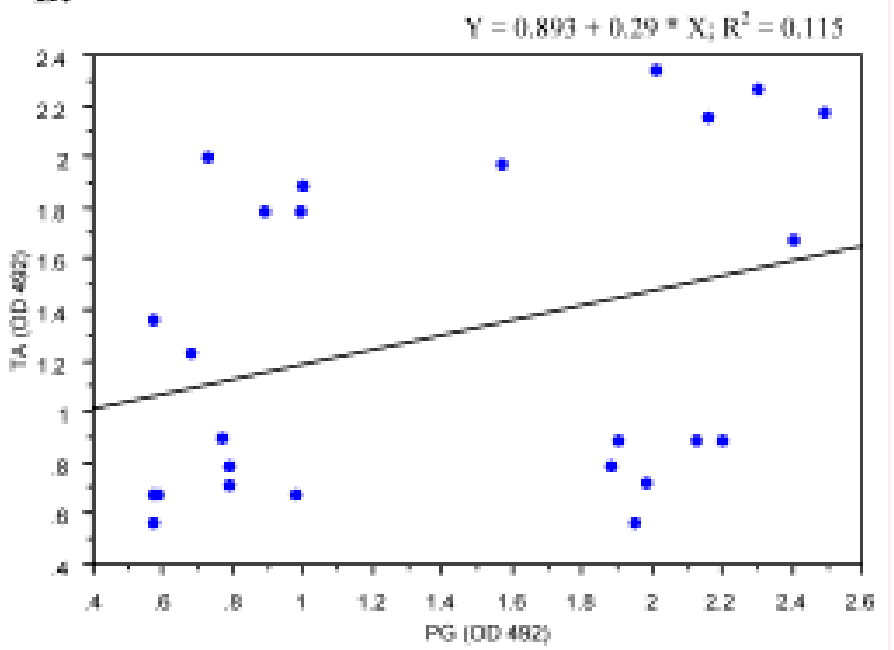

Healthy Superficial Deep-seated 